\title{
Effects of enzyme inoculum mixture on preservation, nutritive value and palatability of grass and clover silages
}

\author{
R Loucka, E Machacova
}

Research Institute of Animal Production, Pratelstvi 815, 10400 Praha 10 - Uhrineves, Czech Republik

Second-crop grass of Becva variety, clover of Kvarta variety, and grass-clover mix (1:1), were ensiled in six special silage containers $\left(7 \mathrm{~m}^{3}\right)$ with and without enzyme inoculum mixture (Bactozym). The silage was stored under the same conditions for each variant tested.

The enzyme component was prepared from cellulase-hemicellulase mixture (25.000 $\mathrm{nkat} / \mathrm{ml}$ ) and glucosidase (4.000 nkat $/ \mathrm{ml})$. The inoculum used was a mixture of Enterococcus faecium M-74, Lactobacillus plantarum, Lactobacillus casei and Pediococcus spp. (CFU : $15 \times 10^{9} / \mathrm{g}$ ). The enzyme-inoculum mixture (mixture of 1 litre of enzyme component with $100 \mathrm{~g}$ of inoculum) was dosed for each 1 ton of forage.

The silage effluent, which flowed continuously for 120 days, was collected and measured daily and was sampled twice during the period for analyses. In silages stored with additive, the outflow of silage effluent was reduced by
$34.8 \%$ in clover silage, by $18.3 \%$ in grassclover mix silage and by $16.4 \%$ in grass silage, compared to silages without additive.

To estimate the nutritive value of silages and their fermentation parameters, routine analytical techniques were employed. The differences between nutritive value and final quality of silages, with and without the enzyme-inoculum mixture, are presented in the following table. Effects of application of the additive to silages are clear.

All silages were tested in a feeding trial with 12 heifers. Voluntary daily intake of grass silages with additive was $8.5 \mathrm{~kg}$ per heifer and without additive $3.6 \mathrm{~kg}$ per heifer. Ad libitum consumption of grass-clover mix silage was $8.4 \mathrm{~kg}$ and $7.0 \mathrm{~kg}$, respectively, and that of clover was $7.7 \mathrm{~kg}$ and $3.8 \mathrm{~kg}$, respectively.

In conclusion, the use of the enzymeinoculum mixture Bactozym improves nutritive value and palatability of silages.

\begin{tabular}{|c|c|c|c|c|c|c|c|}
\hline & \multirow{2}{*}{$\begin{array}{l}\text { Forage } \\
\text { Additive }\end{array}$} & \multicolumn{2}{|c|}{ Clover } & \multicolumn{2}{|c|}{ Mix } & \multicolumn{2}{|c|}{ Grass } \\
\hline & & No & With & No & With & No & With \\
\hline Dry matter & ( $\mathrm{g} / \mathrm{kg}$ fresh matter) & 200 & 191 & 197 & 207 & 200 & 210 \\
\hline Crude protein & (g) & 43 & 46 & 33 & 35 & 27 & 31 \\
\hline PDI & (g) & 16 & 17 & 15 & 17 & 16 & 18 \\
\hline NEL & $(\mathrm{MJ})$ & 0.93 & 0.94 & 0.97 & 1.05 & 1.18 & 1.25 \\
\hline NEV & (MJ) & 0.87 & 0.88 & 0.92 & 0.99 & 1.16 & 1.22 \\
\hline pH & & 4.6 & 4.3 & 4.2 & 4.0 & 4.0 & 3.9 \\
\hline Lactic acid & $(\mathrm{mmol} / \mathrm{l})$ & 1.38 & 1.44 & 1.29 & 1.72 & 1.85 & 1.95 \\
\hline Acetic acid & $(\mathrm{mmol} / \mathrm{l})$ & 1.25 & 1.07 & 1.03 & 1.21 & 0.79 & 0.59 \\
\hline
\end{tabular}

